\title{
BOLOGNA IN THE WESTERN BALKANS: RECONSIDERATION ON HIGHER EDUCATION REFORMS IN THE REGION
}

\begin{abstract}
Over the past two decades, the higher education systems of the so-called Western Balkan countries have experienced several waves of reforms. These reforms have been the result of at least two main factors: the deep political, economic and social changes after 1990 on the one hand, and the challenge of creating a European Higher Education Area (EHEA) on the other. Compared to most European countries, the Bologna reforms in the Western Balkan region have been much more demanding and difficult. The rationale for the reforms hasn't been only modernisation and employability; on the one hand, it has been also about the purposes of higher education and the "European dimension" while, on the other hand, it has been deeply marked by politicization and privatization. In this article we would like to briefly analyse the impact of contemporary European higher education reform on developments and changes in the national higher education systems in the region. To this end, after an introduction we first discuss the changed relationship between the university and the state, then we take a closer look at the two decades of the Bologna Process, and, finally, we present some results of our recent survey on the reforms in the Western Balkans.
\end{abstract}

Keywords: academic autonomy, Bologna Process, centres and peripheries, Europe, higher education reform, Western Balkans.

\section{Introduction: focus on the parts to construct the whole}

Studies in higher education are an interdisciplinary research field established in the United States in the 1960s and 1970s, and Burton R. Clark is considered the founding father of this field. From the eighties onwards, this research perspective spread first to Western Europe and then worldwide. But today, when we analyse the paradigmatic anatomy of these studies, it is not difficult to notice the dominant "Western" tradition. Studies on governance, for example, result mostly from traditions that are specific to North America and Western Europe, and the same also applies to studies of academic culture, although one could expect "softer" and more "pluralistic" approach in this area. Furthermore, when

1 E-mail: pavel.zgaga@pef.uni-lj.si 
it comes to the studies of ongoing higher education reform in different parts of the world, researchers identify the phenomenon of the "policy travel" (Robertson et al., 2012): e.g. a policy which has been formed in given social and historical circumstances is transferred (copy-pasted) as a perfect solution to any other place. Competition for leading positions in the global institutional rankings, etc. are a very good example of this trend.

It is not surprising that so far certain world regions have been extremely well researched, while other, normally small and peripheral regions have remained heavily under-researched and occupy a rather marginal position in the ongoing discussion (Zgaga, 2014). One of these regions is South-Eastern Europe, which is the focus of this paper. However, we are immediately faced with a problem: this is a region for which it is possible to identify as many common characteristics as there are profound differences. When discussing these issues in the contemporary global context in which the specificities of peripheral regions are very little known (and, last but not least, poorly recognized), it is necessary to ask: What precisely do the terms South-Eastern Europe or the Western Balkans refer to?

Understanding that the "West" contains many (well researched!) differences looks normal while the "East" is often submerged in the night in which all cows are black. The division of Europe into "West" and "East" is a relative historical matter. In the XX century, it was manifested as a series of profound political divisions: after 1917 and/or 1945, a geographical term was used to delimit the "democratic" and the "communist" world (border was drawn more eastwards) while after 1990 it began to delimit the "old democracies" and the "transitional countries" (and the border was drawn further westward). Such a blackand-white image allowed not only questionable generalizations but also prejudices. Even in the scientific literature it is not so rare that, for example, certain systemic features of the former Soviet Union system are applied to analyse and explain systems that were different or even contradictory. Such are the cases of two socialist countries from South-Eastern Europe before 1990: the "revisionist"Yugoslavia and the "autarchic" Albania. Each of them was different in its own way. This difference is far from being just an expression of the "pride" of local peoples and their identity. It is a matter of fact that without real knowledge of the parts is not possible to construct the whole. In other words, "emphasizing difference" (Scott, 2006: 430) is inevitable: common features become meaningful only in the light of differences. This is all the more important because after 1990 the differences in the region - i.e. region as an assumption of a relatively "uniform" or "single" space - have become more, rather than less pronounced.

It is paradoxical, but true: in the nineties, when the European higher education systems began to strive for greater compatibility and comparability and promoted the formation of a "single European higher education area" (EHEA), another, much smaller and rather marginal "single higher education space" which existed in one part of the Balkans (at the time of the disintegration of socialist Yugoslavia there were 19 universities in the country with almost 350.000 students and 21 million people; see Zgaga, 2010) ceased to exist. It has been believed that any renewal and eventual reconstruction of this "space" would be possible only by joining the "European trends". The Bologna Declaration devoted a special paragraph to this region, a relatively uncommon practice in such documents: "The importance of education and educational co-operation in the development and strengthening of stable, peaceful and democratic societies is universally acknowledged 
as paramount, the more so in view of the situation in South East Europe" (Bologna Declaration, 1999). Today, however, it can be observed that nationalisms (well-known from the European past, not only from the Western Balkans) are on the rise again, as well as doubts about the strength and sustainability of the European integration policy. It could therefore be in many ways beneficial to provide more case studies on "peripheries", not only on "centres" (Zgaga, 2014).

\section{Shifting the relationship between university and the state}

One of the most noticeable systemic changes after the political turnaround in 1990-1991 was the introduction of a provision on academic freedom and/or autonomy in the constitutions of the new independent countries of the region. In a legal and political sense these two concepts were new and challenging; however, far from being unknown. The Constitution of the SFRY (1974) did not apply them, but in the Preamble (V), and in accordance with the ideology of self-management socialism, it was stated that the "socialist community provides the freedom of creativity and establishes the potential for the development and advancement of education, science, culture and artistic creation, so that the creative ability of the working people may be most successfully developed". Following the dissolution of the federation and landmark political changes at the beginning of the nineties such a definition became useless and obsolete; on the other hand, experience of intellectual opposition and resistance over previous decades put the need for a new constitutional definition high on the agenda. The situation was similar in other countries of Eastern Europe, but the specific "heretic" variant of Yugoslav self-governmental socialism made a very specific impact also on its higher education system and on academic life in general. Here, academic life enjoyed much more freedom (e.g. travel to many Western countries without a visa) than in the countries under the control of the Soviet Union, but fierce clashes with the political authorities were not a rare occurrence.

Virtually all post-1990 Eastern European countries have included some provision on academic freedom and institutional autonomy in their fundamental law, but in various ways and at various times. The most common is that a new constitution ${ }^{2}$ contains provisions both on institutional autonomy and academic freedom; typical definitions can be e.g. "The autonomy of the institutions of higher education shall be ensured" and "Culture, science and research, and teaching shall be free". This pattern was also followed by most of the new states on the territory of the former Yugoslavia. The provision of institutional autonomy hasn't always been guaranteed directly in the constitution, but sometimes provided in special law (e.g. Bosnia and Herzegovina; also in Hungary in 1989/1990).

Everyday life quickly showed that this issue can't be completely resolved by constitutional guarantees only. Gradually, it became clear that the political transition in higher education is not just about the "liberation" of academia from ideological and/or state control; it is primarily about a possible new contract between the state and the university.

2 We have used documents published on Legislationline.org; data and other information available from this site intended for lawmakers across the OSCE (Organisation for Security and Co-operation in Europe) region. 
However, different situations in new independent countries created further deepening differences among reforming education systems. Moreover, the "struggle for autonomy" was still not entirely a thing of the past. In 1998, for example, the Serbian government, led by Slobodan Milošević, adopted a new law on higher education, which encountered unprecedented fierce resistance by students and staff. This law represented a step backwards even when compared to the situation before 1989: inter alia, it was stipulated that the contracts of employment for all academic staff shall terminate (this was a pressure against the critical intelligentsia), that the Rector and other bodies shall be directly appointed by the Government, etc. (In defence of the University, 1998: 151-155).

At that time, the Serbian Constitution contained a guarantee of the "freedom to create and publish scientific and artistic work" (reminiscent of the former socialist period), but not yet of institutional autonomy. Vesna Rakić Vodinelić, Professor of Law at Belgrade University, made an interesting argument against the Law of 1998: "The guarantee of freedom of science also means the guarantee of the freedom of the University as the institutional bearer of science and education. [...] From this basic freedom, legal regulations should arise about a minimum legal guarantee of autonomy (freedom) of the University" (In defence of the University, 1998: 159). Further repression led to growing resistance among students and staff; it fused with the resistance of civil society and finally contributed to the fall of Milošević (2000). However, after this tumultuous period it took a few years to introduce provisions on academic autonomy and freedom in the new Constitution of Serbia (2006), such as we can find in most other "ex-Yu" countries soon after 1990.

A specific interpretation of autonomy (i.e., "autonomy (freedom)") in the quotation above is characteristic not only of Serbia but of most of the region. It is conditioned by historical memory and experiences of either covert tensions between the state and the university, or public controversies and even conflicts (e.g. student movements). According to this interpretation, institutional autonomy can't be reduced to issues of governance and management, but has a direct, genuine relationship with academic freedom: academic (or university) autonomy is basically understood as a guardian, i.e. in the words of RakićVodinelić, "the institutional bearer of science and education".

This is perhaps the essential common conceptual assumption, which underpinned the higher education reforms of the 1990s - at least insofar as we take into account the influence of academics, which was significant during the process of transition (in that period, ministers of education were as a rule academics). Against this background, it can also be understood why the academic autonomy as a compound of academic freedom and institutional autonomy was so strongly represented in the constitutions of the post-1990 era. Comparative analysis has shown that "nearly half the EU states do not have protection for academic freedom and university autonomy written into their constitution"; on the other hand, constitutional protection for freedom of speech and academic freedom is positioned higher in ex-socialist countries than in the rest of Europe (Karran, 2007: 295). A special feature of the transition in the region was the "situation of unfettered autonomy": "instead of clear principles and legislation regulating the relationship between the state and HE providers, academics conceived the reintroduction of autonomy as a political action to accelerate the erosion of totalitarianism" (Dobbins \& Knill, 2009: 411). 
This is why the new higher education laws of the nineties - in some cases even of the 2000s - "were sometimes utopian in their formulations" (Scott, 2006: 433) and lacked the concept of accountability; however, the reality of the transition period led to this utopianism soon being replaced by growing pragmatism: "Autonomy, initially seen largely in terms of an absence of state power, was gradually replaced by new notions of civic and market accountability" (Scott, 2006: 433). However, this process has been very complicated. The former model lost its legitimacy, but elements of the academic culture (such as was formed during previous decades) were at least partly maintained and combined with newly formed ones. This also applies to the understanding of universities as accountable to society: the new concept of accountability has been partly imported from the West, but has also partly been influenced by the previous "quality control" technologies, formulated by the system of self-management socialism (which is today practically unknown). The move from the state control model to a state steering model for public higher education that established the contemporary concept of accountability in West Europe occurred in essentially different circumstances in the East.

This explains to a large extent why some university structures in (post-)transitional countries are still regulated differently than in the so-called traditional democracies. The ideology of the new public management has been either implemented in a different way than in the "countries of origin" or has met with resistance in the traditional academic structures and mentalities. One of the issues that illustrate this aspect very well are the controversies about the independent (or autonomous) faculties in the countries of the former Yugoslavia. In line with the ideology of socialist self-governance, there was an arrangement according to which faculties were autonomous entities with legal personality which were however obliged to "associate" in "communities of higher education institutions", i.e., universities. This provision caused serious fragmentation of the higher education sector, which decision-makers had to face after 1990 in all new countries. There have been several attempts to solve the problem by abolishing "independent faculties" in higher education law, but results have varied greatly from country to country. The problem did not affect only the complex relationship between the state and the university and the issue of accountability; it also created no less complex intra-relationships between the "university members", i.e. faculties, colleges or schools.

The abolition of "independent faculties" was first achieved in Slovenia (1993), but this legal provision was immediately followed by an appeal to the Constitutional Court. After several years of deliberation, the Court concluded: "The Higher Education Act is in conflict with the Constitution, inasmuch as it provides that members [i.e. faculties, schools] of the university are also autonomous". This was, inter alia, based on the grounds that "the autonomy of two or more entities in the same field of decision-making and operation is illogical and may cause only irremediable conflicts". On the other hand, a "fully autonomous social subsystem is an intrinsically contradictory notion: if it is fully autonomous, then it is no longer social neither a subsystem" (Ustavno..., 1998). Thus, the Court confirmed the abolition of the "independent faculties" but also ordered the legislator to regulate the concept of autonomy in the law in more detail. 
A similar case, yet with a completely opposite result, occurred later in Croatia. The Law on Science and Higher Education (2004) introduced the concept of "the legal integration of universities". This concept aimed to abolish university fragmentation, which was to be achieved, in legal terms, through the abolition of the legal personality of faculties and schools and with the "centralization" of all managerial functions. A proceeding was initiated before the Constitutional Court which ended with the Court's decision to abolish the disputed legal provision with the following argument: "The legal personality of the university and the possibility of its components [i.e. faculties, schools] of acquiring legal personality is an expression of university autonomy because autonomy involves a university or other institution of higher education within the university system, as well as each member of the university, that is, each faculty or other organizational unit within each university" (Ustavni ..., 2007).

The issues of academic freedom, institutional autonomy and accountability are among the fundamental questions which determine the structure of a national higher education system. General norms that have been established both by political (Bologna Process) and academic (Magna Charta Universitatum) fora have been formally transferred and introduced into the national legislation of all countries in the region. On the other hand, one cannot overlook the various interpretations that have arisen with the implementation of these principles in the specific environments of individual countries. It is no different even when it is not about general principles, but about the details - the educational system and its structures.

The political (as well as legislative) transition in East Europe of the nineties has been faced with many idiosyncrasies. Even in neighbouring countries with similar traditions the transition in higher education proceeded in different ways, e.g. drawing either on "conservative and reserved legislation" as in the Czech Republic, or on "new, very liberal rules for establishing non-state higher education institutions" as in Poland (Simonová \& Antonowicz, 2006). A comparative study of four Eastern European countries found out that "despite relatively similar starting conditions the differences in higher education governance have increased since the system transformation" (Dobbins \& Knill, 2009: 421). This is also valid for the Western Balkans. In this position, gradual "convergence toward a common model" (ibid.) was possible only due to "the lure of the West" (Scott, 2006: 434-435), efforts after the EU accession and "a powerful role of European agendas" (Kwiek, 2012: 122). In other words, external influences have had a very important role in the reform of higher education, however, as a rule not directly but mediated through traditions and through local power relations. This certainly applies to the effects of the Bologna Process on the countries of this region.

\section{The Bologna Process: the soft policy tool with a strong impact}

From today's perspective, 18 years after its launching, the Bologna Process requires some reflection. At the end of the ministerial conference in June 1999, the expectation that the signed Declaration would mark the beginning of a tremendous shift towards a new 
paradigm would be seen as an exaggeration. Less than ten years later it was clear that this was not so: "Bologna" has become a "European success story" (Budapest-Vienna Declaration, 2010), but at the same time also a matter of ongoing dilemmas, disputes and criticisms. Reactions to the Bologna Process have been quite different in various parts of Europe. Some higher education systems had the opportunity to make good use of it, but in some countries the opportunity was perhaps missed. "Bologna" has made European higher education systems more "comparable and compatible" (Bologna Declaration, 1999), but it has also led to different interpretations and, at least indirectly, emerging new differences.

"Bologna" was not a straightforward implementation of a strategic plan that would be carefully prepared in advance up to its last detail. On the contrary, it was rather a policy idea in process which was received with surprisingly strong interest not only by European ministries responsible for higher education but also by higher education institutions and their stakeholders. It had been developed into a set of "action lines" (i.e., the "Bologna" programme) over a period of at least six years (Zgaga, 2012) - and it has been a result of Zeitgeist.

In the nineties, something was "in the air". All national higher education systems were challenged by massification and by new expectations regarding higher learning. There were also other challenges: the accelerated Europeanisation process (e.g. The Maastricht Treaty, 1992), the turbulent political changes and political opening in Eastern Europe, and increasing global competition in the economy and in higher education as well. Already at the end of the eighties, European academia responded to the first waves of these challenges by "looking forward to far-reaching co-operation between all European nations" in the Magna Charta Universitatum (1991).

European reunification encountered some obstacles, but significantly different from today's. Not a "democratic deficit" (like today), but rather "systemic barriers" were identified and it was recognized that they needed to be removed. European national education systems had evolved into so many different variants that the differences began to present a problem in furthering not only educational but also economic cooperation (e.g. recognition of educational qualifications). Countries and their institutions needed a mutual approach to solving problems. The "Bologna philosophy" (Zgaga, 2012) required developing appropriate "tools" to overcome identified systemic barriers.

A recognition convention, initiated in the early 1990s, solved the issue of higher education qualifications and their possible "substantial differences" (Lisbon Recognition Convention, 1997). The problem also needed to be addressed from other aspects, e.g. different, sometimes even incompatible national educational frameworks, obsolete quality assurance practices, etc. The Sorbonne Declaration (Sorbonne Joint Declaration, 1998) was among the first attempts to address these issues. It called for "harmonisation of the architecture of the European higher education system" - and got some immediate angry responses. "System" or "systems"? "Harmonisation" was a highly disputed term: it seemed to be in contradiction to the subsidiarity principle, i.e. to the (legal) fact that the EU member states remain fully responsible for their educational systems (The Maastricht Treaty, 1992). However, the debate didn't block the initiative; on the contrary. The Bologna Declaration of 1999 avoided the term "harmonisation" and the dispute was soon forgotten. 
The 29 Bologna signatories of 1999 agreed to support "the general principles laid down in the Sorbonne declaration" and promised to engage "in co-ordinating our policies to reach in the short term, and in any case within the first decade of the first millennium" (Bologna Declaration, 1999) the ten "Bologna action lines". Not a uniformed or centralised European system but a development of "easy readable", "comparable" and "compatible" national systems was recognized as the key feature of the European Higher Education Area (EHEA) to be reached by means of convergent national reforms. As a cohesive policy action, "Bologna" has not been only a European answer to specific European problems but also a strategy to become attractive worldwide and to enhance international co-operation and competition.

A particular issue which had to be solved within this period was: which "Europe" fits into the EHEA? An overwhelming majority of the original Bologna signatories came from the "old EU" (15) and EU-associated - since 2004 and 2007 - "new EU" countries (12). The signal sent from Bologna in 1999 met with a surprisingly broad response: by 2005 the Process had expanded to 45 members and its geographic eligibility was shifted to signatories to the European Cultural Convention - i.e. Europe "at large". It was agreed that the EHEA must be universal and opened.

Around 2005, the concept of the emerging EHEA, with most of its details, was fixed and the Process was redirected from the track of conceptualising the EHEA to the track of implementing it. Everyone who has at least some experience with shifting from policy development to implementation knows how complex and complicated this task can be. The Trends 4 report already warned that the experience of introducing new cycles to national systems has demonstrated that it leaves "ample room for different and at times conflicting interpretations regarding the duration and orientation of programmes" (Reichert \& Tauch, 2005). There is "Bologna" - but there are "bolonjas" (small letters and phonetically written) as well. Implementation never really follows original policy ideas in full, but this should not be interpreted simplistically as a "move away from origins" or even as a "betrayal". Conceptualisation and implementation depend on different logics and they are rooted in different grounds - but they also need each another as a mutual corrective force (Zgaga, 2012).

Discussion on possible ways into the emerging EHEA occurred early in the Process and already in the Trends 1 Report (Haug et al., 1999) "four main avenues for combined action" were identified:

(a) a generalised European credit system;

(b) a common, but flexible frame of qualifications;

(c) an enhanced European dimension in quality assurance and evaluation;

(d) empowering Europeans to use the new learning opportunities in Europe.

These "avenues" were concretised in the "Bologna action lines" and fulfilled (at least in the policy documents) by 2010; this is what is commonly understood under "Bologna as the European success story", i.e. the strength of the Process. But success is a doubleedged sword: it is intoxicating but requires responsibility. The main "Bologna" weakness lies in the discomfort of its success: its hegemonic position within on-going discussions on the future of higher education. In popular conversation in particular across the Balkan region the "Bologna" label has been attributed to almost anything that remotely resembles a higher education issue. If authorities wish to push a decision through the process of 
consultation and approval they usually argue: "It has been required by Bologna!" On the other hand, if resisting groups wish to send a strong signal against the proposal they argue: "Look, this has been caused by Bologna!" Pan-bolognasation (Zgaga, 2012) is widespread in today's Western Balkan higher education discourses; it is a strange feature and a counterproductive practice. It would be extremely problematic to attribute to "Bologna" all the problems that arise at the national and institutional level. "Bologna" is a soft policy tool; national and institutional decisions remain in the hands of ministers and rectors. However, this is a tool with a very strong impact, and this is what "local" policy-makers should be aware of.

The main threat to the EHEA has been a trend towards growing instrumentalisation of higher education: changes in its nature, purposes and societal role. In recent times, the implementation task (understood as a technological and not strategic issue) has begun to dominate over conceptualisation (reflection and reconsideration): tools have come to the fore, not ideas and strategic thinking. The question "How?" has overruled the question "What and why?". In other words, "diverse and even conflicting interpretations" have begun to undermine the supposed consensus on the "Bologna action lines". It appears that the major problems with which the process of European integration has been faced over the last decade, are also reflected in the field of higher education.

On the other hand, the instrumentalisation of higher education is not unique to this dimension. In fact, this is a minor aspect. The major issue is the logic which subordinates higher education and the "search for truth" to the machinery of the economy, ignoring warnings that higher education can't be and shouldn't be reduced to one purpose only: either the purpose of serving the industry - or serving a political regime or a church. The last economic crisis has deepened the challenge. Against this background, one of today's key questions for future should be: How to strengthen the role of higher education in modern societies and to preserve and enhance its full range of purposes (Zgaga, 2009)?

On the eve of the big EU enlargement in 2004, the Commissioner Viviane Reding addressed the Forum on cultural rights and education in an enlarged Europe. A quotation from her speech is necessary here: "Our challenge is to build a Europe reaching beyond the sphere of economy to promote sustainable development as a means to meet citizens' expectations concerning quality of life and cultural and social diversity." In addition, it "is the role of culture in the development of European identity without which the Union would be doomed to be nothing more than a vast free trade area" (Reding, 2002: 27). It is with uneasiness that we re-read these words today. Now, Europe looks much closer to "a vast free trade area" and the former "citizens' expectations concerning quality of life and cultural and social diversity" seem not to have been fulfiled. Particularly in the Western Balkans.

\section{"Bologna" and higher education reforms in the Western Balkans}

Higher education developments in the Western Balkans are a widely discussed but under-researched issue. It is only relatively recently that a few researchers from across the region have specialized in the interdisciplinary field of higher education studies (Zgaga, 2014); it is hoped that the situation will improve in the coming years. Below we briefly 
summarize and comment on some of the main findings from a survey, which was recently performed at the Centre for Education Policy Studies (CEPS), University of Ljubljana as an integral part of a larger project on the social and economic consequences of expanded and differentiated higher education systems - internationalisation aspects (Zgaga et al., 2013), supported by a grant from the Slovenian Research Agency (ARRS).

Based on the core part of the project, a survey was conducted in 2012: 16 universities from eight countries (the "Ex-YU" and Albania) were put in focus. In each of the countries the research team focused on two universities: in principle, on the oldest one and on one of the more recently founded universities. Across the region we conducted 78 interviews with academic leaders, with representatives of the ministries and agencies for quality assurance, and with independent experts. A questionnaire was also designed that was completed by 2019 academics, senior and junior professors, lecturers and assistants from these universities. The main findings were published in English (Zgaga et al., 2013). Above all we were interested in reforms since 1990 and the impact of transnational policies on domestic higher education systems and academic culture.

On the surface, the most visible feature of the regional higher education systems over the period at the turn of the century was massification. In the former socialist Yugoslavia, there was a boom in participation rates in the 1970s, but in the 1980s and particularly in the latter half of the decade, this trend slowed down considerably. However, this was not yet a mass higher education (Trow, 2005). In the early 1990s, rates began to climb rapidly again; the rise depended on specific circumstances in each of the newly independent countries. There are several reasons: from a change in cultural patterns and social ambitions to unemployment and migrations to new national policies addressing the national needs and the "upcoming knowledge society" etc. The situation was quite different in territories affected by wars and conflicts. By 2000, in most parts of the region enrolment levels had doubled or tripled (sometimes this trend was slightly delayed, e.g. in Bosnia and Herzegovina and Kosovo) and this trend continued over the next decade, while in this decade it has been gradually slowing down.

Another easily visible feature is the growth in the number of higher education institutions - public and particularly private. It has been already mentioned that at the time of the disintegration of the federal Yugoslavia, there were 19 universities in the country. Three of them were established in the late $19^{\text {th }}$ and early $20^{\text {th }}$ centuries and two of them immediately after World War II. Almost all the others were established in the late 1960s and 1970s to support the decentralised economic development. In Albania, the first university was founded in 1957 and it was the only university there up until 1990, although a few small institutes were also established in this period.

Therefore, in 1990 there were altogether 20 public universities in the region; at the time of our survey, there were 47 public and about 250 private universities and colleges. The expansion of private institutions has been enabled and accelerated by amendments made to legislation after 1990 but it has also been a result of the limited funds available to public higher education and unreasonably high expectations with regard to private initiative in the field. Altogether, this trend has more recently led to sometimes uncontrollable situations both in the private and the public sector. Of course, within this general trend significant specific features are evident from country to country. 
We can conditionally speak about three waves of legislating in the region. In the early 1990s and then throughout the decade, legislators chiefly focused on the general framework which had been profoundly challenged everywhere by the overturn of the political system and by the economic conditions. For example, in many countries of the region the so-called "non-budget" or paying students were introduced at public universities along with "budget-funded" ones and private institutions were legally allowed at this stage.

In the background of this first wave of legislating, the existing higher education policy remained largely the same. There were some attempts to regulate the spontaneity in the field of higher education which had erupted after 1990 but, in general, these predominantly involved technical adaptations of the traditional system to the new political and economic order only. Radical change in the relationship of the university and the state, which we mentioned above, was not very evident during this period. As large parts of the region were affected by wars and conflicts, it would have been unrealistic to expect substantial conceptual shifts and the development of new strategies and policies at this time. Due to the complex circumstances, the first wave of legislating was delayed by about a decade in some countries, e.g. in Bosnia and Herzegovina, Kosovo, Macedonia and Montenegro.

The second wave of legislating occurred at the beginning of the 2000s. On the one hand, it was an obvious task of the post-conflict period and "reintegration into Europe"; on the other hand, it was directly connected to Europeanisation processes and in particular to the Bologna Process. Slovenia joined it in 1999, Croatia in 2001 and the other five countries in 2003; only Kosovo has yet to join it. The legislating agenda of the second wave was stronger, at least at first glance: the common EHEA has provided the conceptual basis for the modernisation of higher education - the basis that had been lacking before in most countries of the region. However, there is much evidence that the desire to "Europeanise" the system overnight too often resulted in cosmetic changes and not in a substantial and strategic conversion.

There is also much evidence that, at least at the beginning of this period, bottom-up incentives to modernise either curricula or governance models at the level of institutions were particularly strong. These incentives were furthered by increasing multilateral cooperation among institutions; Tempus and CEEPUS programmes were particularly influential in this respect. In some countries, elements of the first and second wave emerged simultaneously, e.g. in Macedonia where, after the ethnic conflict of 2001, private universities were allowed under a legal amendment which also provided some incentives leading towards the system's greater openness and internationalisation.

With the progress of the Bologna Process, more amendments have been adopted in all countries. This is the third wave of legislating. Yet at this stage of the reforms another common problem in the policy-making process has become evident: on the one hand, successive and often contradictory amendments have been approved following governmental "swinging" (i.e., "conservative" governments felt a need to change the previous "progressive" legislation, and vice versa). This practice has led to stagnation with regard to long-term national strategic targets. On the other hand, this has also led to specific regional (mis)interpretations of the Bologna Process mentioned above. 
The reforms were generally initiated by the appropriate ministries, not by universities. However, in some countries, academics felt they had been introduced into these initiatives and took part in them. Universities have had a fairly large impact on shaping higher education policy, e.g. in the process of developing the national master plan for higher education in Slovenia (Zgaga et al., 2013). In Macedonia, on the other hand, political negotiations after the slowdown of the ethnic conflicts (2001) provided an opportunity to start changing the traditional law on higher education (Zgaga et al., 2013). This political approach was interpreted at the institutional level as the proper context for speeding up the modernisation of higher education.

However, some interviewees' responses create the impression that even in the countries where academics took part in policy making in previous times, cooperation has in the meantime been eroded. A gradual disillusionment with the "new era" has probably been contributed to the present gloomier picture. An interviewee said that the university is under main pressure from politics (Zgaga et al., 2013). The politicisation of higher education is particularly connected to issues concerning private institutions; almost everywhere they had already been made legally possible during the first wave of legislating. The privatisation of higher education - connected to issues of access and quality assurance and promoted by transnational policy - is obviously a Pandora's box in the Western Balkans. It does not appear that any of the countries have a clear strategy on these issues.

\section{Conclusion}

Almost twenty years after the initiation of the Bologna Process, a question which had been on the agenda in the past should be asked again: Where is our higher education going? Where is our society going? Where should it be going? Let us recall the logic of Magna Charta Universitatum (1991): first, it seriously reconsidered "the fundamental principles" which support "the vocation of universities" and then proceeded with "the means" to attain its "ambitious goals". It seems that today's policy and decision makers are mainly employed by technicistic questions while fundamental questions about strategic conceptual dilemmas are not raised.

Let us help by citing Ulrich Teichler, who has been trying to summarize the problem by formulating a challenging dilemma. Today, he recently argued, emphasis is placed more and more on "elite" higher education with prime attention to the research function of higher education. This has serious consequences for the educational function: the "knowledge society" depends on the elite, while the rest is more or less irrelevant. At this point, Teichler asks if we can move towards an elite knowledge society (where progress depends on the cutting edge knowledge of the chosen few) or towards a mass knowledge society (where progress depends on the wisdom of many (Teichler, 2009) From the perspective of the EHEA future this issue is crucial - and from the perspective of the Western Balkans it is no less crucial. The way in which this dilemma is resolved will be decisive for all countries; however, it might have particularly far-reaching consequences in the EHEA peripheral countries. 


\section{References}

Bologna Declaration (1999). Joint Declaration of the European Ministers of Education of 19 June 1999. Retrieved October 11, 2016 from the World Wide Web

http://www.ehea.info/Uploads/Declarations/BOLOGNA_DECLARATION1.pdf

Budapest-Vienna Declaration (2010). Budapest-Vienna Declaration on the European Higher Education Area. Retrieved October 11, 2016 from the World Wide Web http://www.ehea.info/Uploads/Declarations/Budapest-Vienna_Declaration.pdf

Dobbins, M. \& Knill, Ch. (2009). Higher Education Policies in Central and Eastern Europe: Convergence toward a Common Model? Governance, Vol.22, No. 3, 397-430.

Haug, G., Kirstein, J. \& Knudsen, I. (1999). Trends in Learning Structures in Higher Education [Trends 1]. Project Report for the Bologna Conference on 18-19 June 1999. Copenhagen: The Danish Rectors Conference.

In defence of the University (1998). Beograd: Beogradski krug.

Karran, T. (2007). Academic Freedom in Europe: A Preliminary Comparative Analysis. Higher Education Policy, Vol. 20, No. 3, 289-313.

Kwiek, M. (2012). Universities and Knowledge Production in Central Europe. European Educational Research Journal, Vol. 11, No. 1, 111-126.

Lisbon Convention (1997). Convention on the Recognition of Qualifications concerning Higher Education in the European Region. Retrieved August 27, 2016 from the World Wide Web http://conventions.coe.int/Treaty/en/Treaties/Html/165.htm

Magna Charta Universitatum (1991). Bologna, 18 settembre 1988. Retrieved October 11, 2016 from the World Wide Web http://conventions.coe.int/Treaty/en/Treaties/Html/165.htm

Reding, V. (2002), Forum 'Culture, Cultural Rights and Education in an Enlarged Europe'. In J. De Groof \& G. Lauwers (Eds.), Cultural and Educational Rights in the Enlarged Europe (pp. 27-34). Nijmegen: Wolf Legal Publishers.

Reichert, S. \& Tauch, Ch. (2005). Trends 4: European Universities Implementing Bologna. Brussels: EUA - European University Association.

Robertson, S., Dale, R. Moutsios, S., Nielsen, G., Shore, Ch. \& Wright, S. (2012). Globalisation and Regionalisation in Higher Education: Toward a New Conceptual Framework. Working Papers on University Reform; Working Paper 20. Aarhus: Department of Education, University of Aarhus. Retrieved October 11, 2016 from the World Wide Web http://edu.au.dk/fileadmin/www.dpu.dk/forskningsprogrammer/epoke/WP_20_-_final.pdf

Scott, P. (2006). Higher Education in Central and Eastern Europe. In J. F. Forest, Ph. G. Altbach (Eds.), International Handbook of Higher Education (423-441). Part Two: Regions and Countries. Dordrecht: Springer.

Simonová, N. \& Antonowicz, D. (2006). Czech and Polish Higher Education - from Bureaucracy to Market Competition. Czech Sociological Review, Vol. 42, No. 3, 517-536.

Sorbonne JointDeclaration (1998).JointDeclaration on Harmonisation of the ArchitectureoftheEuropean Higher Education System. Paris, Sorbonne. Retrieved October 11, 2016 from the World Wide Web http://www.ehea.info/Uploads/Declarations/SORBONNE_DECLARATION1.pdf 
Teichler, U. (2009). Higher Education and What World of Work? Rotterdam: Sense Publishers. Retrieved October 11, 2016 from the World Wide Web https://www.sensepublishers.com/media/469-higher-education-and-the-world-of-work.pdf

The Maastricht Treaty (1992). Provisions Amending the Treaty Establishing the European Economic Community with a View to establishing the European Community. Maastricht, 7 February 1992. Retrieved October 18, 2016 from the World Wide Web https://europa.eu/european-union/sites/ europaeu/files/docs/body/treaty_on_european_union_en.pdf

Trow, M.A. (2005). Reflections on the Transition from Elite to Mass to Universal Access: Forms and Phases of Higher Education in Modern Societies since WW II. Working Papers, Berkeley: Institute of Governmental Studies. Retrieved August 29, 2016 from the World Wide Web http://escholarship.org/uc/item/96p3s213

Ustavni sud Republike Hrvatske (2007). Odluka UI-1707/2006. Official Gazette of RH, No. 2/2007.

Ustavno sodišče Republike Slovenije (1998). Odločitev U-I-34/94. Official Gazette of RS, No. 18/98.

Zgaga, P. (2009) Higher Education and Citizenship: "The Full Range of Purposes". European Educational Research Journal, Vol. 8, No. 2, 175-188.

Zgaga, P. (2010). The Role of Higher Education in National Development: South-Eastern Europe and Reconstruction of the Western Balkans. London and New York: Routledge. Retrieved October 11, 2016 from the World Wide Web http://www.educationarena.com/pdf/sample/sample-essay-zgaga.pdf

Zgaga, P. (2012). Reconsidering the EHEA Principles: Is There a 'Bologna Philosophy'? In A. Curaj, P. Scott, L. Vlasceanu \& L. Wilson (Eds.), European Higher Education at the Crossroads: Between the Bologna Process and National Reforms (pp. 17-38). Dordrecht: Springer.

Zgaga, P. (2014). The Role of Higher Education Centres in Research and Policy: A Case from a European Periphery. Studies in Higher Education, Vol. 39, No. 8, 1393-1404.

Zgaga, P., Teichler, U., \& Brennan, J. (Eds.) (2013). The Globalisation Challenge for European Higher Education. Convergence and Diversity, Centres and Peripheries. Frankfurt: Peter Lang.

Zgaga, P., Klemenčič, M., Komljenovič, J., Miklavič, K., Repac, I. \& Jakačić, V. (2013). Higher Education in the Western Balkans: Reforms, Developments, Trends. Ljubljana: CEPS, University of Ljubljana. 


\title{
БОЛОЊА НА ЗАПАДНОМ БАЛКАНУ: ПРЕИСПИТИВАЊЕ РЕФОРМИ ВИСОКОГ ОБРАЗОВАЬА У РЕГИОНУ
}

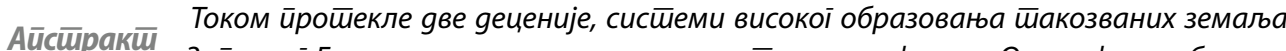
Зайаgної Балкана gоживели су неколико шиаласа реформи. Ове реформе биле су

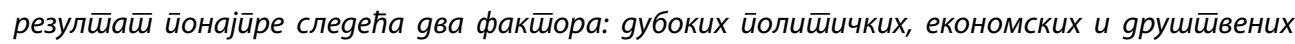
иромена йосле 1990. іолине, с јеgне, и изазова сишварања јеgинсиивеної Евройскої ӣросйора високої образовања (EHEA), с gруїе сйране. Уйоређењу са већином евройских земаља, Болоюска реформа у реїиону зайаgної Балкана била је захйевнија и иежа. С јеgне сйране, разлози за йокрешиање реформе били су модернизачија и зайошљивосй, као и намена високої образована u „Евройска gимензија,, али је она, с gруіе сииране, била gубоко обележена йолишизацијом и

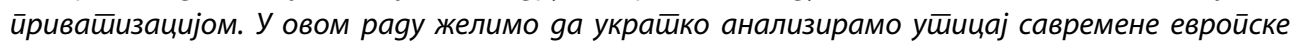
реформе високої образовања на развој и иромене у начионалним сисиемима високої образована у реїиону. С шиим ииљем, након увоgа, у йексйу се йрво анализира йишиане

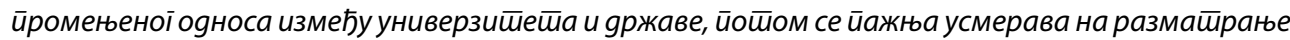

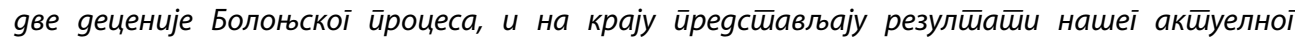
исирраживана о реформама у реїиону зайаgної Балкана.
\end{abstract}

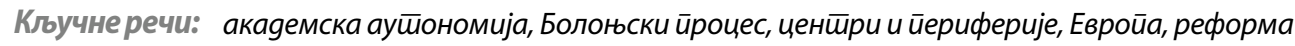
високої образовања, Зайаяни Балкан.

\section{БОЛОНСКИЙ ПРОЦЕСС НА ЗАПАДНЫХ БАЛКАНАХ: ПЕРЕСМОТР РЕФОРМ ВЫСШЕГО ОБРАЗОВАНИЯ В РЕГИОНЕ}

\begin{abstract}
Резюме
В течение последних 20 лет системы высшего образования в так называемых странах Западных Балкан пережили несколько волн реформ. Эти реформы были прежде всего результатом двух факторов: глубоких политических, экономических и сочиальных изменений после 1990 года и проблем, связанных с созданием единого европейского пространства высшего образования (ЕHЕA). По сравнению с большинством европейских стран, Болонская реформа на Балканах была более требовательной и трудной. С одной стороны, причинами проведения реформы были модернизачия и трудоустройство, а также предназначение высшего образования и «европейское измерение», но с другой стороны, эта реформа прошла под знаком глубокой политизачии и приватизации. В данной статье в сжатой форме рассматривается влияние современной европейской реформы высшего образования на развитие и изменение национальных систем высшего образования в регионе. После введения, в статье сначала анализируется проблема измененных отношений между университетом игосударством, затем вниманиеуделяется рассмотрениюдвухдесятилетий Болонского процесса и в коние статьи приводятся результаты нашего актуального исследования о реформе систем образования в странах Западных Балкан.
\end{abstract}

Ключевые слова: академическая автономия, Болонский прочесс, чентр и периферия, Европа, реформа высшего образования, Западные Балканы. 